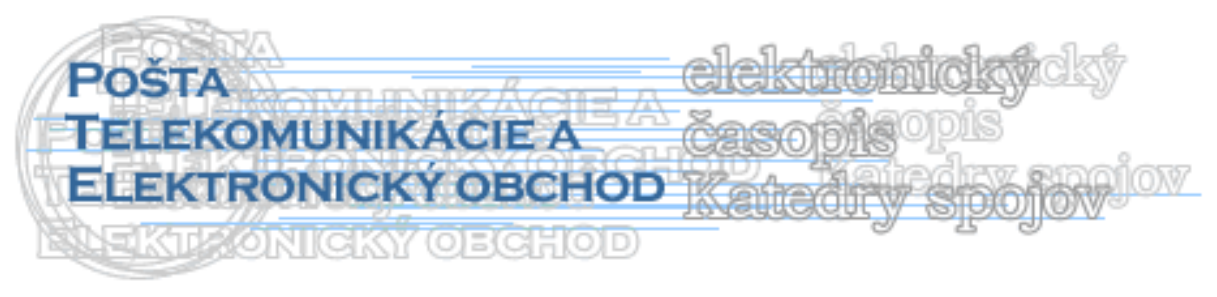

\title{
ÚLOHA SYSTÉMU ZNALOSTNÉHO MANAŽMENTU V EFEKTÍVNOM RIADENÍ PODNIKU
}

\author{
Miroslava Mikušová *
}

\section{Úvod}

Hoci efektívnost' a konkurencieschopnost' podnikov v trhovej ekonomike ovplyvňujú nad’alej faktory ako úroveň technológií, existujúca podniková kultúra, stupeň využívania najnovších informácií a pod., rozhodujúcim aspektom úspechu sa v dnešnej dobe stáva intelektuálny kapitál - l’udia a efektívne využívanie ich potenciálu znalostí, ktorému sú v konečnom dôsledku všetky ostatné faktory podriadené.

Snád' práve $\mathrm{z}$ tohto dôvodu je $\mathrm{v}$ súčasnosti čoraz väčšia pozornost' venovaná riadeniu znalostí, ktoré sa stáva moderným smerom manažmentu, úzko prepojeným so všetkými úrovňami a fázami tradičných manažérskych aktivít.

\section{Vymedzenie a základná charakteristika znalostného manažmentu}

Znalostný manažment, známy pod anglickým výrazom knowledge manažment, v sebe obsahuje všetky aspekty súvisiace so znalost’ami, teda ich vznik, normalizáciu, transformáciu, ukladanie do pamäti, výber, spracovanie, šírenie, rozvíjanie a využívanie. Nejde však len o zhromažd'ovanie vzájomne previazaných informácií, ale skôr o pokrytie konkrétnych potrieb reálneho procesu riadenia a zaistenie všetkých pre podnik dôležitých informácií.

Znalostný manažment je vlastne efektívnym prepojením tých, ktorí vedia, s tými, ktorí vediet' potrebujú, premenou osobných vedomostí (tacitných) na organizačné vedomosti (explicitné) formou komunikácie, zapojenia a zdiel'ania.

Vedenia podnikov by sa mali snažit' o systematické zhromažd'ovanie individuálnych znalostí svojich zamestnancov a o ich transformovanie do podoby, ktorá by umožňovala ich opätovné použitie, čo by malo zabezpečit' aj to, aby podnik nebol bytostne závislý od konkrétnych l'udí, ktorí sú v nej momentálne zamestnaní. Podstatné znalosti by mali byt' zdiel'ané viacerými zamestnancami a vo podniku by sa mali neustále vytvárat' nové poznatky ako aj nové hodnoty.

\section{Podporné prostriedky znalostného manažmentu}

Ideálnou platformou na budovanie systémov znalostného manažmentu je Intranet, ktorý má dosah na takmer všetkých zamestnancov, čo dáva predpoklady nepretržitej a obojstrannej komunikácie.

\footnotetext{
* Ing. Miroslava Mikušová, PhD., Fakulta prevádzky a ekonomiky dopravy a spojov, Žilinská univerzita v Žiline, Univerzitná 1, 01026 Žilina, tel.: +421415133564, fax: +421415655615 e-mail: Miroslava.Mikusova@fpedas.uniza.sk
} 
Vhodným prostriedkom je aj Internet. Tento môže byt' využívaný ako priestor pre komunikáciu so zákazníkom, kedy sa pri existencii vhodných aplikácií pre záznam všetkých transakcií a komunikácií stáva pre manažment ako aj pracovníkov podniku nevyčerpatel'nou studnicou informácií, ktoré po analyzovaní a pretavení do nových postupov a praktík smerujú k tvorbe kvalitnej znalostnej databázy. Inou formou aplikácie v podnikových procesoch je jeho využívanie ako zdroja informácií najrozmanitejšieho charakteru, ktoré sú pravidelne vyhodnocované, klasifikované a predkladané zodpovedným pracovníkom.

Ďalšími využitel'nými technológiami sú napríklad [2] :

- technológie push a inteligentní agenti - ul’ahčujú orientáciu v záplave informácií a autorizujú transfer dôležitých informácií priamo k jej požadovatel’ovi.

- aplikácie Help-Desk - majú podobnú funkciu. Umožňujú nájst' v databáze poznatkov a riešení rýchlu odpoved’ na otázku kladenú klientom, kolegom alebo zamestnancom.

- brainstormingové aplikácie - pomáhajú zvýšit' kreatívnost', pomáhajú tiež kategorizovat', organizovat' a odhal'ovat' jednotlivé zdroje poznatkov a tak ul'ahčujú orientáciu a napomáhajú kreatívnosti.

- skladištia dát a datamining nástroje - sú obrovské priestory dát, ktoré umožňujú manažérom získat' hodnotné poznatky potrebné na optimalizáciu vzt'ahov so zákazníkmi, objavenie nových trhov, zákazníkov, produktov.

\section{Predpoklady budovania systému znalostného manažmentu}

Systémy riadenia poznatkov je možné budovat' len $\mathrm{v}$ podnikoch, vyznačujúcich sa vyspelou podnikovou kultúrou. Najväčším problémom v tomto kontexte bývajú zvyklosti a postoje l'udí. Poväčšine ide o neochotu zamestnancov delit' sa o často obtiažne získané poznatky. L'udia stále vnímajú svoje znalosti ako záruku, ktorá im zaist'uje ich pracovné miesto, a preto sa zdráhajú o ne podelit' s inými. Pritom si neuvedomujú súvislost' medzi svojou schopnost'ou pracovat' $\mathrm{s}$ informáciami, znalost’ami a úspechom organizácie. Pre mnohých je tiež t’ažké orientovat' sa v záplave nových informácií, ktoré prúdia do organizácie prostredníctvom časopisov, výskumov trhov, prieskumov verejnej mienky a atd'.

Konkrétnou podmienkou existencie znalostného manažmentu vpodniku je tzv. knowledge-sharing kultúra. Je to ochota delit' sa o svoje vedomosti, poznatky a skúsenosti a dovolit' tak všetkým zamestnancom profitovat' v prospech celej organizácie. Nejde však len o ich vôl'u podelit' sa o svoje poznatky. Rovnako dôležité je, či pre ostatných tieto vedomosti znamenajú určitý prínos, prípadne, či sú schopní pochopit' kontext, v ktorom dané poznatky vznikli a či sú ochotní tieto vedomosti prijat', osvojit' si ich a používat'. Z podobných predpokladov vychádza teória učiacej sa organizácie, ktorá je zároveň predpokladom správnej aplikácie znalostného manažmentu.

\section{Systém znalostného manažmentu v podniku Correos y Telégrafos}

Príkladom fungujúceho riadenia poznatkov je systém znalostného manažmentu vybudovaný v španielskom podniku Sociedad Estatal Correos y Telégrafos, s.a. (d'alej len Correos y Telégrafos), ktorý tejto organizácii pomohol v úspešnom prispôsobení sa pomerne rýchlej liberalizácii trhu poštových služieb.

Correos y Telégrafos je dominantným poštovým operátorom na území Španielska, v súčasnosti štátnym podnikom, patriacim pod Ministerstvo rozvoja Španielskeho král'ovstva, ktorého hlavným predmetom činnosti je poskytovanie poštových a telegrafických služieb. So svojimi viac ako 68.000 stálymi zamestnancami patrí Correos y Telégrafos medzi najvýznamnejších zamestnávatel'ov v Španielsku. Siet' kontaktných bodov dosahuje číslo 10.050, pričom z nich 4100 sú poštové prevádzky. Disponuje približne 35.000 poštovými 
schránkami, rozmiestnenými po celej krajine. Každý deň spracováva poštové zásielky v objeme 16 miliónov kusov, pričom ročne to býva viac ako 5900 miliónov zásielok distribuovaných do 19 miliónov domácností a 2 miliónov podnikov. Vozový park tvorí 12 500 vlastných vozidiel a 600 prenajímaných vozidiel.

Od júla 1998 bol tento podnik na základe udelenej poštovej licencie zodpovedný za poskytovanie univerzálnych poštových služieb, t. zn. súboru vyhradených služieb, poskytovaných na celom území krajiny za rovnakých podmienok, v rovnakej kvalite a za prijatel'né ceny, v stanovených minimálnych časových intervaloch. S uvedeným úzko súvisí nepriama kompenzácia zo strany štátu za finančné bremeno vyplývajúce z povinnosti poskytovat' univerzálnu poštovú službu za prijatel'né resp. regulované ceny. V súčasnosti je značná čast' týchto služieb plne liberalizovaná. Proces liberalizácie bol však pre podnik značne komplikovaný, nakol'ko pre toto odvetvie je prirodzené, že na trhu existovali niekol'ko desat'ročí monopolné organizácie (Rostášová, 2006, s.62). S tým súvisí potreba využívania moderných manažérskych nástrojov, ktoré napomohli úspešnému uplatneniu sa podniku na trhu aj napriek nevyhnutnosti dodržiavania harmonogramu znižovania poštovej výhrady v súlade s platnou európskou a následne prispôsobenou národnou legislatívou.

\section{Vznik potreby vybudovania systému znalostného manažmentu}

Dôvodom vzniku potreby zmien $\mathrm{v}$ oblasti riadenia poznatkov bola čoraz rýchlejšia transformácia prostredia, $\mathrm{v}$ ktorom Correos y Telégrafos realizuje svoje aktivity spolu $\mathrm{s}$ viacerými zmenami právneho štatútu, ktorými v posledných rokoch tento podnik prešiel.

V minulosti bol v podniku Correos y Telégrafos kladený dôraz predovšetkým na oblast' interných poznatkov. Základným predpokladom úspechu bola dokonalá znalost' platného Národného predpisu o poštových službách (Reglamento de los Servicios Postales), ktorý určoval podrobné charakteristiky procesu poskytovania služby. Smernice organizácie boli zamerané na poskytnutie záruky dodržiavania práv užívatel'ov (na takmer monopolistickom trhu) a na presnost' poskytovania služieb. Z popísaného kontextu je zrejmá opodstatnenost' existencie kontrolného orgánu, ktorý mal za úlohu zaručit' dôsledné plnenie uvedených predpisov.

Absencia systému pre zdiel'anie informácií viedla $\mathrm{k}$ vzniku sietí $\mathrm{s}$ internými informáciami, ktoré sa stali podpornými systémami pre prijímanie rozhodnutí. Napriek tomu mimo určitých okruhov informácie vôbec neexistovali. Vývoj udalostí ukázal, že rovnako potrebné sú aj externé poznatky, teda poznatky o trhu, o zákazníckych požiadavkách ako aj o aktivitách konkurentov. Výsledkom bol vznik potreby rozšírenia ponuky produktov a služieb, vrátane vytvárania personalizovaných ponúk pre klientov.

Ďalšou nevyhnutnost’ou v rámci novej etapy rozvoja podniku sa stala aplikácia nových technológii a snaha o aktívne zapojenie sa do procesu internacionalizácie, s ciel'om chránit' svoje záujmy $v$ rámci Európy a rozvíjat' sa na nových trhoch, napr. v Strednej Amerike. Ochrana vlastných záujmov v Európe viedla $\mathrm{k}$ potrebe detailného poznania európskeho regulačného rámca, tak $\mathrm{v}$ oblasti poštovej prevádzky ako aj $\mathrm{v}$ oblasti konkurenčných podmienok, a $\mathrm{k}$ čo najlepšiemu pochopeniu aktivít konkurentov $\mathrm{v}$ procese prípravy spojenectiev a joint-ventures.

\section{Aktivity v oblasti znalostného manažmentu}

Za účelom získania a šírenia poznatkov Correos y Telégrafos inicioval množstvo aktivít zameraných interne aj externe. 
Vzhl'adom na územné rozčlenenie a široký zamestnanecký park si vedenie podniku za jeden zo základných ciel'ov vytýčilo identifikovat' a interne šírit' najlepšie praxe svojich zamestnancov. Z tohto dôvodu bol iniciovaný program Innova, zameraný na identifikáciu a spoznanie prínosných podnetov a nasledovaniahodných praxí. Daný program bol podporovaný siet'ou 14-tich územných koordinátorov kvality, ktorých poslaním bola zhromažd'ovanie, analýza a hodnotenie spomínaných informácií. Následne boli prínosné návrhy ako aj identifikované najlepšie praxe odmeňované a $v$ organizácii d'alej šírené. $Z$ troch nominovaných kandidátov bol tiež každoročne volený národný výherný tým, ktorému bola na výročnom fóre kvality odovzdaná prémia.

Okrem toho podnik zvýšil svoju účast' na fórach a konferenciách, v špecializovaných asociáciách a medzinárodných organizáciách. Príkladom je napr. jej členstvo $\mathrm{v}$ troch národných asociáciách kvality: v AEC, Klube riadenia kvality (Club de Gestión de Calidad) a Iberoamerickej nadácii pre kvalitu (Fundación Iberoamericana para la Calidad). Táto účast' okrem iného umožňuje spoznávat' najlepšie praxe, ktoré vykonávajú podniky a organizácie vyznačujúce sa rozvinutým systémom kvality, ako aj možnost' zapojit' sa do už existujúcich systémov benchmarkingu.

Podnik sa tiež zameral na zvýšenie využívania Internetu pre získavanie relevantných informácií o svojich konkurentoch a pre mapovanie situácie v oblasti regulačných zmien, $\mathrm{v}$ oblasti technologického vývoja ako aj pre skúmanie produktov a služieb požadovaných trhom.

Za účelom „mobilizácie" poznatkov potrebných pre zavádzanie inovácií a pre podporu rozhodovania na strategickej a riadiacej úrovni vznikli virtuálne spoločenstvá prepojené firemným Intranetom.

Jedným z výsledkom predstavených aktivít bolo rozšírenie produktového portfólia o široké spektrum elektronických služieb (napr. posielanie listov, pohl'adníc, dokumentov a elektronických notifikácií, asistencia pri exporte, albarany doručenia a pod.

\section{Záver}

Na základe skúsenosti popísanej v tomto príspevku je možné zhodnotit', že riadenie poznatkov v dnešnej dobe patrí medzi kl'účové faktory podmieňujúce úspech firmy. Potreba neustáleho zavádzania inovácií za účelom adaptovania sa na nové požiadavky užívatel'ov, potreba poskytovania kvalitných služieb a potreba transformácie sa, ktoré sú pre úspešné pokračovanie pôsobenia podnikov $\mathrm{v}$ meniacom sa trhovom prostredí mimoriadne dôležité a vedú $\mathrm{k}$ nevyhnutnosti zavádzania systémov riadenia poznatkov. Pre podniky sa stáva nadmieru dôležité trvalé vytváranie nových znalostí, ich efektívne využívanie v rámci organizácie ako aj maximálne možné úročenie v nových výrobkoch a službách.

Príklad Correos y Telégrafos potvrdzuje, že napriek st’aženým legislatívnym a iným podmienkam je vd’aka vhodne zvoleným manažérskym nástrojom možné udržanie, dokonca i zlepšenie trhového postavenia podniku.

\section{Literatúra}

[1] Collison, Ch., Parcel, G.: Knowledge management. Brno, Computer Press, 2005, ISBN 80-251-0760-4

[2] Bureš V: Znalostní managemnet a proces jeho zavádení. Grada Publishing, Praha, 2007, ISBN 978-80-247-1978-8

[3] Rostášová M., Bát'ka M.: Poštová výhrada a liberalizácia na európskom poštovom trhu. In: Pošta, Telekomunikácie a Elektronický obchod 2/2006, ISSN 1336-8281

[4] Dirección de Control de Gestión y Administración: Acciones para la mejora en Correos y 
Telégrafos. Informe de gestión 2001(interný podnikový dokument)

[5] Memoria annual 2007 (http://www.correos.es) [31.12.2007]

[6] Hlavné smery rozvoja európskeho poštového odvetvia

(http://www.telecom.gov.sk/index/index.php?ids=1861) [17.9.2009] 